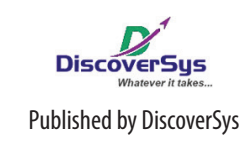

\section{Cervical cancer screening among reproductive-aged women: a crossectional survey in Tabanan Regency}

\author{
Desak Gede Yenny Apriani, ${ }^{1,2^{*}}$ Ni Luh Putu Suariyani, ${ }^{2,3}$ \\ I Nyoman Mangku Karmaya ${ }^{2,4}$
}

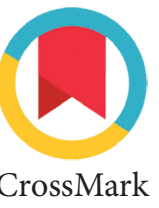

\section{ABSTRACT}

Background and purpose: Cervical and breast cancers are the most common malignancies among women in Indonesia. The prevalence of cervical cancer in Bali was $0.6 \%$ in 2013. Screening coverage for cervical cancer in Tabanan district varies from 37\% to 67\%. This study aims to determine factors associated to cervical cancer screening uptake among reproductive-aged women.

Methods: A cross-sectional survey was conducted at Baturiti Subdistrict, Tabanan Regency, Bali Province. This study involved 188 reproductive-aged women. Samples were randomly selected from all reproductive-aged women from two villages of Baturiti and Angseri. Data were collected using home interviews by a standardised questionnaire. Multivariate analysis was conducted using poisson regression model to determine factors associated to cervical cancer screening uptake.

Results: This study showed that the proportion of cervical cancer screening was $38.83 \%$. Variables associated to the uptake of cervical cancer screening were comprehensive knowledge about cervical cancer $(A P R=10.16 ; 95 \% C l: 4.33-24.76)$, insurance holder (APR=2.95; 95\%Cl: $1.38-6.64)$ and aged of $\geq 40$ years (APR=1.26; $95 \%(\mathrm{Cl}$ : $1.01-1.59)$. Education level, employment status and perceived benefits were not associated with the screening uptake among reproductive-aged women. Conclusions: Level of knowledge about cervical cancer, insurance ownership and aged over 40 years increase the cervical screening uptake among reproductive-aged women.
${ }^{1}$ Institute of Health Science Advaita Medika Tabanan,

${ }^{2}$ Public Health Postgraduate Program Udayana University, ${ }^{3}$ chool of Public Health Faculty of Medicine Udayana University, ${ }^{4}$ Department of Anatomy Faculty of Medicine Udayana University.
*Correspondence to: Desak Gede Yenny Apriani, Institute of Health Science Advaita Medika Tabanan, Public Health Postgraduate Program Udayana University yennyapriani2004@gmail.com

Keywords: cervical cancer screening, acetic acid visual inspection, Tabanan Cite This Article: Apriani, D.G.Y., Suariyani, N.L.P., Karmaya, I.N.M. 2017. Cervical cancer screening among reproductive-aged women: a crossectional survey in Tabanan Regency. Public Health and Preventive Medicine Archive 5(1): 14-18. D01:10.15562/phpma.v5i1.35

\section{INTRODUCTION}

Reproductive health is a state of complete physical, mental and social well-being of all reproductive system, and not merely the absence of disease and disability. ${ }^{1}$ One of many reproductive health problems in Indonesia is the high prevalence of cervical cancer among reproductive-aged women. ${ }^{2}$

Cervical cancer is the second highest cancer among reproductive-aged women after breast cancer. Annually, about 15,000 new cervical cancer cases were reported in Indonesia with mortality rate of 8,000 per year. ${ }^{3}$ Data from Basic Health Survey (Riskesdas) 2013 showed that the prevalence of cervical cancer in Indonesia was $0.8 \%$ and Bali Province was ranked $6^{\text {th }}$ with the prevalence of $0.6 \%{ }^{4}$ The reported cervical cancer cases in Tabanan District Health Office were 57 cases (2009), 44 cases (2010), 53 cases (2011), 60 cases (2012), 74 cases (2013) and 30 cases (up to August 2014). ${ }^{5}$

The coverage of cervical cancer screening remains low because cervical cancer at early stage is asymptomatic. ${ }^{6}$ Screening for cervical cancer can be done using two methods - visual inspection with acetic acid (or called IVA) and pap smear. Data from Tabanan District Health Office showed that the coverage of IVA test was $67 \%$ in 2014, and the lowest coverage of $37 \%$ was found in Baturiti I Public Health Centre. ${ }^{5}$

This study aims to determine factors associated to the uptake of cervical cancer screening. The conceptual framework in this study adopted from PRECEDE-PROCEED Model introduced by Green and the Health Belief Model (HBM) that include predisposing factors (age, education level, employment status, economic status, level of knowledge and perception), enabling factors (health insurance ownership) and reinforcing factors (family support). ${ }^{7}$

\section{METHODS}

A cross-sectional survey was conducted from April, $30^{\text {th }}$ to May, 28 ${ }^{\text {th }}$ 2016. Study population were married reproductive aged women (between 20-49 years) and were residing at Baturiti I Public Health Centre working areas during the data collection. From a total of six villages, two were randomly selected that were Angseri Village (956 eligible population) and Baturiti Village (1347 eligible population). A total of 188 samples were selected using systematic random sampling consisted of 78 samples from Angseri Village and 110 from Baturiti Village. Data on age, education, employment, income, level of knowledge, health insurance 
Table 1 Characteristics of respondents

\begin{tabular}{lc}
\hline Characteristic & $\mathbf{n}(\%)$ \\
\hline Age (year) & \\
$\quad$ Mean \pm SD & $35.31 \pm 7.40$ \\
$<40$ & $123(65.4)$ \\
$\geq 40$ & $65(34.6)$ \\
Education & \\
Elementary and junior high & $106(56.4)$ \\
Senior high & $73(38.8)$ \\
University & $9(4.8)$ \\
Employment & \\
Farm worker & $29(15.4)$ \\
Farmer & $58(30.9)$ \\
Private/informal sectors & $88(46.8)$ \\
Office worker & $13(6.9)$ \\
Income (IDR) & \\
Mean \pm SD & \\
$<2.500 .000$ & $2,952,660 \pm 768,667$ \\
$\geq 2.500 .000$ & $60(31.9)$ \\
Total & $128(68.1)$ \\
\hline
\end{tabular}

Table 2 Cervical cancer screening uptake among respondents

\begin{tabular}{lc}
\hline Variables & $\mathbf{n}(\%)$ \\
\hline Screening behaviour & \\
Never screened & $115(61.2)$ \\
Ever screened & $73(38.8)$ \\
$\quad$ IVA & $46(24.5)$ \\
$\quad$ Pap Smear & $11(5.8)$ \\
$\quad$ IVA and Pap Smear & $16(8.5)$ \\
Reasons for not taking screening tests* & \\
Shame & $97(84.4)$ \\
Reluctant & $24(20.9)$ \\
Financial reason & $49(42.6)$ \\
Not important & $2(1.7)$ \\
Asymtomatic & $31(26.9)$ \\
Afraid & $50(43.5)$ \\
Screening frequency & \\
1 time & $38(52.0)$ \\
2 times & $23(31.5)$ \\
4 times & $10(13.7)$ \\
$>5$ times & $1(1.4)$ \\
\hline
\end{tabular}

$\left.{ }^{\star}\right)$ Each respondent can provide more than one reason ownership, family support and cervical screening uptake were collected using home individual interviews and lasted for about 20 minutes. Informed consent was obtained prior to interviews. Data were analysed using univariate, bivariate and multivariate analysis with Stata 12.1. Univariate analysis was conducted to describe characteristics of respondents and frequency distribution of all variables. Bivariate analysis was conducted to generate cross-tabulation between independent variables and the uptake of cervical cancer screening. Poisson regression test was employed to measure adjusted prevalence ratio (APR) using confidence interval at 95\%. This study protocol has been approved by Human Research Ethics Committee of Faculty of Medicine Udayana University/Sanglah General Hospital.

\section{RESULTS}

Table 1 shows the frequency distribution of respondent characteristics that include age, education level, employment status, and incomes. The average age was 35.31 years $(\mathrm{SD}=7.40)$ and the mean incomes was IDR 2,952,660 (SD=IDR 768,667).

Table 2 shows the uptake of cervical cancer screening among all samples. As many as $38.8 \%$ samples were screened for cervical cancer which consisted of $24.5 \%$ with IVA test, $5.8 \%$ with pap smear and $8.5 \%$ with both tests. The majority of respondents (52\%) were screened only one time and $4.8 \%$ were screened for four times or more. The main reasons for not doing the screening were shame $(84.4 \%)$, afraid (43.5\%), financial reason (42.6\%), asymptomatic $(26.9 \%)$, reluctant $(20.9 \%)$ and not important (1.7\%).

Table 3 shows the association between independent variables and the uptake of cervical cancer screening using chi-square test.

Several variables found to have significant association with the cervical cancer screening uptake were age, level of education, employment, income, self efficacy, health insurance ownership, perceived benefits, perceived susceptibility and family support.

Bivariate analysis revealed that there were twelve variables with $p$-value of $<0.25$ and all were included in the poisson regression analysis as presented in Table 4. It showed that only three variables were significantly associated with improved uptake that were age $(\mathrm{APR}=1.26 ; 95 \% \mathrm{CI}$ : 1.01-1.59), level of knowledge (APR $=0.16 ; 95 \% \mathrm{CI}: 4.23-24.38)$ and health insurance ownership (APR $=2.95 \quad(95 \%$ CI: 1.34-6.50). 
Table 3 Association between independent variables and the cervical cancer screening uptake

\begin{tabular}{|c|c|c|c|}
\hline \multirow[b]{2}{*}{ Characteristic } & \multicolumn{2}{|c|}{ Cervical cancer screening uptake } & \multirow[b]{2}{*}{ p value } \\
\hline & $\begin{array}{c}\text { Yes } \\
\text { n (\%) }\end{array}$ & $\begin{array}{c}\text { No } \\
\text { n (\%) }\end{array}$ & \\
\hline \multicolumn{4}{|l|}{ Age } \\
\hline$<40$ & $42(27.9)$ & $81(72.1)$ & 0.007 \\
\hline$\geq 40$ & $31(48.1)$ & $34(51.9)$ & \\
\hline \multicolumn{4}{|l|}{ Education } \\
\hline Elementary and junior high school & $33(31.1)$ & $73(68.9)$ & 0.029 \\
\hline Senior high school & $37(50.7)$ & $36(49.3)$ & \\
\hline University & $3(33.3)$ & $6(66.7)$ & \\
\hline \multicolumn{4}{|l|}{ Employment } \\
\hline Farm worker & $9(31.1)$ & $20(68.9)$ & $<0.001$ \\
\hline Farmer & $12(20.7)$ & $46(79.3)$ & \\
\hline Private/informal sector & $48(54.5)$ & $40(45.5)$ & \\
\hline Office worker & $4(30.8)$ & $9(69.2)$ & \\
\hline \multicolumn{4}{|l|}{ Income (IDR) } \\
\hline$<2,500,000$ & $0(0.0)$ & $60(100.0)$ & $<0.001$ \\
\hline$\geq 2,500,000$ & $73(57.1)$ & $55(42.9)$ & \\
\hline \multicolumn{4}{|l|}{ Insurance ownership } \\
\hline No & $5(9.4)$ & $48(90.6)$ & $<0.001$ \\
\hline Yes & $68(50.4)$ & $67(49.6)$ & \\
\hline \multicolumn{4}{|l|}{ Level of knowledge } \\
\hline Low & $5(5.6)$ & $85(94.4)$ & $<0.001$ \\
\hline High & $68(69.4)$ & $30(30.6)$ & \\
\hline \multicolumn{4}{|l|}{ Perceived vulnerability } \\
\hline Yes & $72(53.7)$ & $62(46.3)$ & $<0.001$ \\
\hline No & $1(10.0)$ & $9(90.0)$ & \\
\hline Unknown & $0(0.0)$ & $44(100.0)$ & \\
\hline \multicolumn{4}{|l|}{ Perceived severity } \\
\hline Low & $0(0.0)$ & $79(100.0)$ & $<0.001$ \\
\hline High & $73(66.9)$ & $36(33.1)$ & \\
\hline \multicolumn{4}{|l|}{ Perceived benefit } \\
\hline Low & $20(20.2)$ & $79(79.8)$ & \\
\hline High & $53(59.5)$ & $36(40.5)$ & $<0.001$ \\
\hline \multicolumn{4}{|l|}{ Perceived barrier } \\
\hline Low & $71(66.4)$ & $36(33.6)$ & $<0.001$ \\
\hline High & $2(2.5)$ & $79(97.5)$ & \\
\hline \multicolumn{4}{|l|}{ Self efficacy } \\
\hline Low & $3(3.7)$ & $78(96.3)$ & $<0.001$ \\
\hline High & $70(65.4)$ & $37(34.6)$ & \\
\hline \multicolumn{4}{|l|}{ Family support } \\
\hline Low & $5(5.6)$ & $84(94.4)$ & \\
\hline High & $68(68.7)$ & $31(31.3)$ & $<0.001$ \\
\hline
\end{tabular}

Table 4 Factors associated to the cervical cancer screening uptake

\begin{tabular}{lccc}
\hline Variables & APR & $\mathbf{9 5 \% C l}$ & p value \\
\hline Age $\geq 40$ & 1.26 & $1.01-1.59$ & 0.039 \\
Good level of knowledge & 10.16 & $4.23-24.38$ & $<0.001$ \\
Health insurance ownership & 2.95 & $1.34-6.50$ & 0.007 \\
\hline
\end{tabular}




\section{DISCUSSION}

The majority of respondents in this study were aged $<40$ years, had low education level, worked at the private/informal sectors and had a low monthly income. As many as $38.8 \%$ respondents underwent cervical cancer screening and the majority were only screened for one time. The national target for the cervical cancer screening uptake is $80 \%{ }^{8}$ The public health centre in the study location conducts the mobile IVA screening from one village to another and is provided for free. However, the maximum number of women for every screening program is only 20 women. It is more likely that only the same women will come for the next screening. Women who wish to take pap smear test should visit the public health centre or private midwives. These might lead to the low coverage of the uptake of cervical cancer screening.

A number of main reasons inhibited respondents to do the screening were shame $(84.4 \%)$, afraid of the test and the result $(43.5 \%)$, financial reason $(42.6 \%)$ and not aware due to asymptomatic (26.9\%). Other study also found that shame is the main barrier for women to undertake the screening test and women from low income families are more reluctant to take the screening as they prefer to spend their income toward other basic needs instead of IVA or pap-smear tests. ${ }^{9}$ In the present study, income is not a significant barrier.

Several factors were found to have significant association with the cervical screening uptake among women that were age, level of knowledge and health insurance ownership. Older respondents (age $\geq 40$ years) are more inclined to take the screening (APR=1.26; 95\%CI: 1.01-1.59). This finding is in accordance to the guideline from the Ministry of Health of Indonesia which suggests that women aged between 30-50 years must take cervical cancer screening. ${ }^{8}$ Other study however found that there is no significant association between age and IVA test uptake. ${ }^{10}$

High level of knowledge about cervical cancer improves the screening uptake $(\mathrm{APR}=10.16$; 95\%CI: 4.23-24.38). Study in Kebumen found similar finding (APR=2.021; 95\%CI: 1.508-2.709). ${ }^{11}$ Study conducted in Denpasar and Tabanan districts showed that level of knowledge is associated with the uptake of cervical cancer screening $(\mathrm{p}=0.03) .{ }^{12}$

Health insurance holders tend to participate in the screening program than non-insurance holders. This finding is consistent with other study. ${ }^{13}$ Women with income $<$ IDR 2,500,000 are more reluctant to take the screening. The majority of women who attended IVA screening program in this present study were from middle income families. Women attending IVA screening program were mainly head of village's wife and surrounding community members, which probably came from a wealthier family. Low income women are less likely to attend IVA screening program.

Findings from this study suggest that a more systematic monitoring and evaluation to improve coverage of cervical cancer screening is required, especially targeting women from low social economic background and who reside far from the village centre.

This study only involved limited areas thus findings from this study cannot be generalized into a wider area. Further in depth qualitative research is required to explore factors associated to the uptake of cervical cancer screening.

\section{CONCLUSION}

The uptake of cervical cancer screening at Baturiti I Public Health Centre is low. Several factors associated with the screening uptake are level of knowledge, insurance ownership and age.

\section{ACKNOWLEDGEMENT}

We would like to thank the Head of Baturiti I Public Health Centre and all respondents who had participated in this study.

\section{REFERENCES}

1. National Demographic and Family Planning Agency. Peningkatan Partisipasi Pria Dalam Keluarga Berencana dan Kesehatan Reproduksi [Improving men participation in family planning and reproductive health]. Jakarta: BKKBN; 2001.

2. Winarto. Kanker Serviks dan Infeksi Human Pappilomavirus (HPV) [Cervical cancer and Human Pappilomavirus Infection]. Jakarta: Javamedia Network; 2008.

3. The Indonesian Cancer Association. Cara Cerdas Menghadapi Kanker Serviks [The smart ways to overcome cervical cancer]. Yogyakarta: Genius Printika; 2010.

4. Reseach and Development Agency of Ministry of Health of Indonesia. Riset Kesehatan Dasar Tahun 2013 [Basic Health Survey 2013]. Jakarta: Departemen Kesehatan RI; 2013

5. Tabanan District Health Office. Rekapan Kegiatan IVA Kabupaten Tabanan tahun 2010-2014 [Recapitulation of IVA program at Tabanan District from 2010-2014]; 2014.

6. WHO. Comprehensive Cervical Cancer Control A Guide to Essential Practice. Geneva: World Health Organization; 2006.

7. Green L. Health Education Planning. California : Mayfields Publishing Co; 1991.

8. Ministry of Health of Indonesia. Pedoman Pengendalian Kanker Serviks [National guideline to address cervical cancer]. Jakarta: Direktorat Pengendalian Penyakit Tidak Menular PP\&PL; 2009.

9. Winingsih. Faktor Determinan Pemanfaatan Layanan Deteksi Dini Kanker Leher Rahim pada WUS di Desa Tegal Kertha Wilayah Kerja Puskesmas 1 Denpasar Barat Tahun 2012 [Determinants for the uptake of cervical cancer screening among reproductive aged women in Tegal Kertha Village, West Denpasar I Community Health Centre]. Denpasar: UNUD; 2012. 
10. Hartati. Motivasi Wanita Usia Subur untuk Melakukan Pemeriksaan Inspeksi Visual Asam Asetat [Motivations of reproductive-aged women to undertake IVA test]. Jurnal Gema Keperawatan; 2014.

11. Yuliawati. Faktor-faktor yang Berhubungan dengan Perilaku WUS dalam Deteksi Dini Kanker Leher Rahim Metode IVA di Wilayah Puskesmas Prembun Kabupaten Kebumen Tahun 2012 [Factors associated to IVA test among reproductive-aged women in Prembun Community Health Centre, Kebumen District]. Jakarta: FKM UI; 2012.

12. Suarniti. Pengetahuan dan Motivasi Wanita Usia Subur Tentang Tes Inspeksi Visual Asam Asetat di Propinsi Bali [Level of knowledge and motivation of reproductive aged women to undertake IVA test in Bali Province]. Bandung: Program Studi Magister Kebidanan Fakultas Kedokteran Universitas Padjadjaran; 2013.
13. Rahma, Gusni. Hubungan Jaminan Pembiayaan Asuransi Kesehatan dengan Ketahanan Hidup Lima Tahun Pasien Kanker Serviks di Rumah Sakit Cipto Mangunkusumo [Association between health insurance ownership and five years survival rate of cervical cancer patients at Cipto Mangunkusumo Hospital]. Jakarta: FKM UI; 2012.

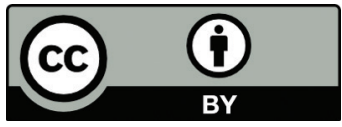

This work is licensed under a Creative Commons Attribution 